\title{
Pengaruh Strategi Pemasaran Syariah, Kepuasan Konsumen dan Kepercayaan Konsumen Terhadap Loyalitas Konsumen (Studi Kasus pada Naughti Hijab Store)
}

\author{
Sumadi $^{\left.1^{*}\right)}$, Muhammad Tho'in ${ }^{2)}$, Tino Feri Efendi ${ }^{3)}$, Diyah Permatasari ${ }^{4)}$ \\ ${ }^{1,2,4}$ Fakultas Ekonomi Bisnis, Institut Teknologi Bisnis AAS Indonesia \\ ${ }^{3}$ Fakultas Teknologi, Institut Teknologi Bisnis AAS Indonesia \\ *Email korespondensi: sumadi@stie-aas.ac.id
}

\begin{abstract}
This study aims to find evidence of the influence of Sharia Marketing Strategy, Consumer Satisfaction, and Consumer Confidence. This type of research is quantitative research. The population in this study are consumers at Naughti Hijab Store. The sampling technique used is using the Slovin formula. The sample in this study in this amounted to 100 respondents Naughti Hijab Store cunsumers. In this study using four variables, namely sharia marketing strategy, consumer satisfaction, and consumer confidence as independent variables and consumer loyalty as the dependent variable. This study uses multiple linear regression analysis method with the help of SPSS. The results showed that the sharia marketing strategy had a positive and significant effect on consumer loyalty, consumer satisfaction did not have a positive and significant effect on consumer loyalty, and consumer confidence had a positive and significant effect on consumer loyalty. From the results of multiple linear regression analysis, the coefficient of each variable is obtained, namely sharia marketing strategy 0,000, consumer satisfaction at 0.081, and consumer confidence at 0,016.
\end{abstract}

Keywords: Sharia Marketing Strategy, Consumer Satisfaction, Consumer Trust, Consumer Loyalty.

Saran sitasi: Sumadi., Tho'in, M., Efendi, T. F. \& Permatasari, D. (2021). Pengaruh Strategi Pemasaran Syariah, Kepuasan Konsumen dan Kepercayaan Konsumen Terhadap Loyalitas Konsumen (Studi Kasus pada Naughti Hijab Store). Jurnal Ilmiah Ekonomi Islam, 7(02), 1117-1127. doi: http://dx.doi.org/10.29040/jiei.v7i2.2562

DOI: http://dx.doi.org/10.29040/jiei.v7i2.2562

\section{PENDAHULUAN}

Era globalisasi saat ini memberikan dampak yang sangat luas terhadap pertumbuhan dunia fashion muslim di Indonesia yang sangat beragam. Dengan berkembangnya fashion muslim saat ini, maka setiap toko berusaha memunculkan produk unggulannya atau koleksi-koleksi yang saat ini lagi ngetrend dipasaran atau yang banyak diminati oleh para konsumen.Para pelaku bisnis terutama dalam pemasaran telah mengalami transformasi mulai dari level intelektual (rasional) menuju pada emosional dan pada akhirnya berganti kepasar spiritual. Akhirnya konsumen cenderung mempertimbangkan kesesuaian produk yang ditawarkan juga jasa yang diberikan pada nilai spiritual yang diyakini akan sesuai dengan apa yang ditawarkan oleh penjual. Berubah dari hal ini maka muncul asumsi baru bahwa dalam perkembangan dunia pemasaran harus dilandasi oleh kebutuhan pokok dan dasar seorang penjual, diantaranya yaitu kejujuran, moral, dan etika dalam bisnis yang menjadi suatu pedoman dalam strategi pemasaran syariah yang akan diterapkan (Mubarok, 2017).

Melihat persaingan usaha fashion muslim yang berkembang saat ini yang semakin kompetitif dalam menawarkan produk unggulan mereka, maka Naughti Hijab Store harus lebih berusaha untuk membangun hubungan dalam jangka panjang dengan para konsumen yang sudah datang ke toko maupun secara online yang sudah membeli produk mereka. Konsumen yang menjadi fokus utama bagi setiap toko untuk bisa menjalin hubungan dengan baik dengan para konsumen agar mereka bisa terus membeli produk ditoko kita dengan cara meningkatkan kualitas pelayanan dan memberikan produk yang sesuai serta nyata yang ditawarkan dengan kualitas yang baik pula 


\section{Jurnal Ilmiah Ekonomi Islam, 7(02), 2021, 1118}

maka para konsumen akan kembali lagi ketoko kita dan itu akan menimbulkan loyalitas konsumen dengan produk yang ditawarkan serta jasa yang diberikan dengan baik kepada mereka.

Untuk itu Naughti Hijab Store berusaha untuk memberikan pelayanan yang terbaik kepada konsumennya yang sudah membeli produk ditokonya, serta berusaha mendapat apresiasi penilaian-penilaian yang positif dari para konsumen yang sangat besar. Hal itu mempengaruhi kepuasan para konsumen yang sudah datang dan membeli produk kita, akan menciptakan loyalitas konsumen terhadap toko. Dengan menciptakan suatu loyalitas konsumen terhadap toko maka konsumen yang sangat loyal bukan hanya sangat berpotensi menjadi word of mouth advertisers, namun juga kemungkinan besar loyalitas pada produk dan pelayanan atas jasa yang kita berikan secara semaksimal mungkin (Sri Mulyani, 2018).

\section{KAJIAN TEORI}

\section{Strategi Pemasaran Syariah}

Menurut para ahli (Mubarok, 2017) yang mengemukakan tentang pengertian strategi diantaranya adalah: Steiner dan Milner, mengemukakan bahwa penerapan strategi adalah penetapan misi dari sebuah perusahaan untuk menetapkan sasaran organisasi dalam meningkatkan kekuatan eksternal serta internal, dengan adanya kebijakan dan implementasi sebuah perusahaan secara tepat akan mencapai tujuan dengan sasaran utama sebuah organisasi yang akan tercapai. Strategi pemasaran merupakan rangkaian dari sebuah tujuan serta sasaran pasar, kebijakan yang diaturakan memberikan arahan kepada perusahaan pemasar dalam jangka waktu tertentu, dan juga dalam masingmasing tingkatan, acuan juga alokasinya, juga sebagai tanggapan bagi sebuah perusahaan untuk menghadapi lingkungan yang pesaingnya selalu berubah pada segmen suatu pasar.

Dalam pemasaran diibaratkan dalam suatu persaingan untuk para penjual yang bergerak dibidang komoditas yang sama juga perlu untuk menciptakan strategi pemasaran untuk pelaku pasar juga dapat memenangkan segmen pasar suatu perusahaan. Beberapa para ahli mengemukakan pendapatnya mengenai pengertian strategi pemasaran sebagai berikut:

a. Menurut Tjiptono, strategi pemasaran yaitu suatu fundamental yang dirancang untuk mencapai suatu tujuan untuk sebuah perusahaan dalam melakukan perkembangan dalam sebuah persaingan yang seimbang untuk melalui segmen pasar yang akan dimasuki juga program yang telah digunakan untuk melayani sasaran pasar.

b. Menurut Philip Kotler, strategi pemasaran adalah sebuah pola pikir yang akan digunakan untuk sebuah strategi yang dilakukan untuk mencapai pemasaran yang menguntungkan bagi perusahaan, juga mengenai strategi spesifik dalam sasaran segmen pasar, penetapan posisi, juga pemasaran serta seberapa besar untuk pengeluaran pemasaran.

Unsur Strategi Pemasaran Menurut Guitinan dan Paul (Mubarok, 2017) strategi pemasaran meliputi sebagai berikut:

a. Segmentasi pasar, merupakan salah satu tindakan yang dilakukan dimana untuk mengidentifikasi dan akan membentuk suatu kelompok konsumen secara terpisah. Para konsumen yang sudah dibedakan yaitu menurut karakteristik kebutuhan produk-produk juga berkaitan dengan sebuah pemasaran.

b. Targeting, merupakan suatu tindakan yang dipilih dalam segmen pasar untuk memasuki suatu targeting pada suatu segmen pasar yang akan perlu dievakuasi yaitu:

1) Ukuran dan pertumbuhan segmen perusahaan untuk mengevakuasi suatu data sebagai tingkatan permintaan dalam segmen pasar, dan juga tingkat pertumbuhan sebuah pasar juga tingkat keuntungan yang mengharapkan seberapa besar sasaran pada segmen pasar yang dituju.

2) Daya tarik segmen pasar, juga menjadi sebuah ukuran dalam suatu pertumbuhan segmen pasar bagi suatu perusahaan yang akan mempertimbangkan faktor untuk mempengaruhi daya tarik jangka panjang pada suatu segmen pasar tentunya.

3) Sasaran dan sumber daya sebuah perusahaan akan meningkat apabila suatu perusahaan tersebut menentukan sasaran pasar juga sumber daya yang tepat agar dapat bersaing disegmen pasar yang dituju sebuah perusahaan.

c. Positioning, merupakan salah satu penetapan sebuah posisi segmen pasar, yang berguna untuk mencapai dan mampu membangun serta mengkomunikasikan keunggulan sebuah produk yang ditawarkan kepada para konsumen (Mubarok, 2017). 


\section{Jurnal Ilmiah Ekonomi Islam, 7(02), 2021, 1119}

Strategi pemasaran merupakan wujud dari suatu rencana yang sudah terarah dibidang pemasaran untuk memperoleh keuntungan yang optimal bagi para pelaku bisnis terntunya. Dalam suatu pemasaran juga setiap langkah dapat memformulasikan suatu yang harus diorientasikan pada suatu upaya untuk pencapaian sebuah kepuasan konsumen dan juga pada sebuah produk yang akan ditawarkan pada sebuah segmen pasar yang ditembus. Itu merupakan suatu proses yang akan ditempuh pada setiap perusahaan sangat bermacam-macam yang sesuai dengan kesanggupan perusahaan sebagai karakteristik dari masing-masing perusahaan, juga menjadi sebuah tujuannya yang tetap akan mencapai kepuasan konsumen (Amirotun, 2016).

Segmentasi pasar sebagai pengetahuan untuk menjadi perancangan situasi strategi pemasaran yang baru atau sebagai perubahan strategi yang sudah ada sebelumnya antara lain :

a. Perancangan Strategi Pemasaran (designing marketing strategy). Menjadi tahap suatu analisis dalam situasi juga suatu proses strategi pemasaran yang digunakan untuk mengidentifikasi bagi peluang pasar, menggambarkan segmen pasar, mengevaluasi persaingan, dan juga memiliki kelemahan-kelemahan serta terdapat kekuatan bagi sebuah perusahaan. Perancangan strategi pemasaran derdapat atau meliputi market targeting dan juga sebagai analisis positioning, membangun hubungan erat dengan para pelaku pasar yang lain, dan pengembangan serta memperkenalkan sebuah produk baru yang akan diedarkan untuk para konsumen.

b. Pengembangan Program Pemasaran (marketing program development). Tahap pengembangan program pemasaran ini meliputi portofolio, rantai nilai, strategi promosi dan juga harga.

c. Penerapan dan Manajemen Strategi Pemasaran (Implomating and managing marketing strategy). Tahap yang mungkin akan digunakan untuk penerapan dan manajemen sebuah strategi pemasaran dapat meliputi perancangan marketing driven organization yang efektif, serta startegi implementasi dan kontrol. Tiap perusahaan tersendiri dalam menyusun strategi pemasaran akan berbeda-beda yang sesuai dengan sebuah rencana dalam jangka pendek maupun jangka panjang dan juga menjadi suatu pokok yang begitu penting bagi perusahaan. Walaupun banyak terdapat berbagai macam perencanaan juga pokok yang disorot terhadap hal-hal yang harus terdapat dalam sebuah rencana. Misalnya rencana pada produk dan rencana pemberian merek harus terdapat atau memuat: rangkuman penata laksanaan, tujuan dan sasaran, penegasan strategi, program kegiatan, anggaran, pengawasan.

Makna harfiah syariah dalam mendapatkan jalan menuju sumber kehidupan. Secara etimologi syariah berasal dari bahasa arab yaitu syara'a, yasyra'u, syar'an wasyari'atan yang berarti sebagai jalan keluar ketempat air. Dengan kata ini dipengaruhi oleh bangsa arab dengan adanya jalan yang lurus dan benar yang harus dituntut oleh umat islam dalam menjalankan sebuah usahanya. Sedangkan dalam bahasa terminologi syariah sendiri mempunyai arti sebagai sebuah jalan yang sudah ditetapkan oleh Tuhan yang harus membuat manusia untuk mengarahkan kehidupannya dalam mewujudkan kehendak Tuhan supaya dalam hidupnya selalu bahagia di dunia maupun diakhirat. Penjelasan ini dapat meliputi semua panduan dari Allah untuk hamba-Nya.

Strategi pemasaran syariah seluruh aktivitasnya dilakukan dengan suatu perencanaan yang baik. Dan juga Islam mengajarkan bahwa semua perencanaan tidak lain memanfaatkan "karunia Allah", secara sistematik dengan memperhatikan kebutuhan konsumen dan nilai kehidupan yang berubah-ubah. Dalam hal ini dapat diartikan secara luas bahwa suatu perencanaan menyangkut persiapan menyusun rancangan setiap kegiatan ekonomi. Konsep ini tentang perencanaan yang harus dipahami dalam arti terbatas yang diakui dalam islam. Tujuannya untuk kesenangan konsumen dengan cara memanfaatkan sumber yang disediakan oleh Allah SWT.

Dalam Hadis Nabi dari Anas ibn Malik yang diriwayatkan oleh al-bukhari dan muslim: "Barangsiapa ingin agar rezekinya dilapangkan dan pengaruhnya diluaskan maka hendaknya ia menyambung tali silahturahmi". Dari sini dapat disimpulkan bahwa dalam suatu usaha kegiatan pemasaran harus melakukan silahturahmi dengan para konsumen. Karena dengan menjaga silahturahmi dengan para konsumen dapat menjaga hubungan baik dengan mereka dan apabila para pemasar semakin banyak bertemu dengan banyak konsumen, semakin banyak pula relasi yang dikenal dan akan semakin memperpanjang tali silahturahmi dengan para konsumen. 
Dalam strategi pemasaran syariah akan ada suatu strategi-strategi pemasaran yang akan dikenal sebagai tujuan pemasaran. Tujuan pemasaran itu sendiri sebagai alat bagi pemasaran yang sudah ada dalam berbagai unsur-unsur suatu program pemasaran yang telah diperlukan juga dipertimbangkan supaya tujuan strategi pemasaran dan positioning yang diterapkan dapat berjalan dengan sukses. Perencanaan pemasaran biasanya terjadi dan disusun berdasarkan $4 \mathrm{P}$ yang menjadi suatu indikator-indikator yaitu: product (produk), price (harga), place (tempat), promotion (promosi).

\section{Kepuasan Konsumen}

Menurut Kotler (Agustina, 2018) kepuasan kosumen merupakan sebuah tingkatan dimana suatu produk yang dinilai sesuai dengan harapan para konsumen yang sudah membeli produk yang ditawarkan untuk mereka.

Menurut Armistead dan Clark (Adi, 2017) kepuasan konsumen merupakan suatu konsep pemasaran dan sudah melalui penelitian para konsumen. Sudah menjadi pendapat secara umum bahwa seorang konsumen akan merasa puas dengan suatu produk atau merek yang ditawarkan, mereka akan cenderung terus membeli dan menggunakan produk kita juga akan memberi tahu orang lain tentang pengalaman mereka yang menyenangkan dengan produk-produk kita. Jika mereka tidak puas dengan pelayanan dan produk kita maka merekaakan cenderung beralih merek dan juga mereka akan melakukan komplain terhadap pemasar. Kepuasan para konsumen yaitu sebuah hal yang sangat berpengaruh untuk berjalannya suatu bisnis atau usaha yang dijalankan. Layanan yang diberikan kepada para konsumen akan memicu kepuasan bagi seorang konsumen atas pelayanan yang diberikan. Beberapa pelaku pemasar telah lama menyadari bahwa produk yang banyak diminati oleh konsumen tidaklah cukup untuk menarik para konsumen karena yang lebih penting untuk membuat para konsumen kembali membeli produk yang ditawarkan.

Banyak toko yang tidak dapat mencapai sasaran penjualan, hal ini sering dikarenakan oleh kurang tepatnya suatu toko dalam memberikan suatu strategi kepuasan konsumen, sehingga kesetiaan konsumen terhadap barang atau jasa yang ditawarkan akan sulit untuk dipertahankan. Untuk mempertahankan konsumen yang sudah ada, pihak pelaku bisnis dituntut untuk selalu tanggap terhadap apa yang diinginkan oleh setiap konsumen. Kepuasan konsumen yang akan diperoleh para konsumen salah satunya hal yang paling penting sebagai rancangan bagi sebuah perusahaan yaitu menciptakan kepuasan konsumen terhadap produk kita. Konsumen yang merasa puas akan tercipta apabila produk yang digunakan akan memenuhi harapan bagi para konsumen. Dengan adanya konsumen yang merasa puas terhadap produk yang dibeli maka akan mengurangi keluhan dalam menggunakan produk yang kita tawarkan. Kepuasan konsumen merupakan hal yang akan menjadikan loyalitas konsumen terhadap produk kita (Widyaninggar, 2015).

Menurut garvin (Septia, 2015), indikatorindikator yang dapat mempengaruhi suatu kepuasan konsumen antara lain sebagai berikut :

a. Komunikasi

Yaitu dimana kemampuan menyampaikan informasi kepada para konsumen dalam bahasa yang nudah dipahami oleh konsumen, serta selalu mendengarkan saran dan juga keluhan para konsumen.

b. Kepercayaan

Sifat yang harus di harus menjadikan setiap karyawannya selalu berbuat jujur dalam menyampaikan kualitas produk yang ditawarkan maka itu akan mendapatkan kepercayaan terhadap konsumen.

c. Keamanan

Yaitu bebas dari bahaya, resiko maupun keraguraguan.

d. Memahami konsumen

Sebisa mungkin kita memahami konsumen dan kebutuhan spesifik para konsumen, dengan cara memberikan perhatian individual, mengenal kebutuhan konsumen.

e. Kemampuan

Penguasaan keterampilan dalam memahami produk yang kita tawarkan dan juga pengetahuan yang dibutuhkan supaya dapat melayani sesuai dengan kebutuhan konsumen.

f. Kesopanan

Yaitu sikap santun, respek, atensi, dan juga keramahan para karyawan dalam melayani konsumen. Jika mereka menerapkan sikap yang ramah maka para konsumen akan merasa senang dan puas terhadap pelayanan yang kita berikan kepada mereka (Septia, 2015).

\section{Kepercayaan Konsumen}

Kepercayaan konsumen yaitu sebagai kesediaan seseorang untuk menggantungkan hidupnya kepada 
seorang pihak lain yang memiliki tujuan yang sama dengan mereka. Kepercayaan konsumen itu sebagai keyakinan mereka untuk menjadikan sebuah janji yang ditawarkan oleh penjual yang dapat diandalkan dan dipercaya bahwa pihak tersebutakan memenuhi kebutuhannya yang sesuai dengan yang mereka butuhkan saat ini maupun kebutuhan yang akan datang (Syaifullah, 2018).

Menurut Lenin kumar, 2017 (Putra, 2018) kepercayaan konsumen merupakan pengaruh yang sangat penting apabila konsumen itu merasa kalau pemenuhan kebutuhan atau produsen itu dapat diandalkan untuk bertindak demi kebutuhan para konsumen yang terbaik untuk mereka saat mereka menghadapi kontak langsung dengan para konsumen. Kepercayaan konsumen itu sangat berhubungan erat dengan adanya suatu kepuasan yang akan diperoleh para konsumen dalam suatu produk, jasa dan layanan yang ditawarkan untuk mereka. Kepercayaan konsumen akan muncul karena adanya kepuasan yang akan diperoleh para konsumen terhadap produk, jasa dan layanan yang dirasakan mereka terhadap pelayanan yang diberikan oleh para penjual (Putra, 2018).

Membangun sebuah kepercayaan akan sangat berpengaruh penting dalam membangun kepercayaan karena apabila kepercayaan konsumen itu akan menjadi suatu kunci keberhasilan dalam suatu usaha mereka dalam jangka yang sangat panjang. Morgan dan Hunt (Bahrudin, 2015) mengutarakan pendapatnya bahwa kepercayaan yaitu sebuah variabel kunci yang digunakan untuk mengembangkan suatu keinginan yang tahan lama terhadap suatu hubungan dalam jangka panjang yang akan dijalin antara penjual dengan pembeli. Kepercayaan itu akan muncul untuk membangun persepsi para konsumen, apakah merek yang mereka itu memiliki integritas dan kompetensi dengan produk pesaing. Maka itu akan mempengaruhi sikap dan perilaku para konsumen (Bahrudin, 2015).

Indikator-indikator dalam suatu kepercayaan konsumen menurut Nuraini, 2009 (Monica, 2015) kepercayaan terbentuk dari tiga hal yaitu: Kejujuran penjual dalam bertransaksi, Tanggungjawab penjual kepada pembeli, Kepercayaan bahwa perusahaan memiliki reputasi yang baik.

\section{Loyalitas Konsumen}

Loyalitas konsumen merupakan ada setiap konsumen yang terus menggunakan produk yang kita tawarkan pada mereka jika mereka merasa puas dengan produk kita juga perilaku dimana para konsumen diharapkan dapat menjadi loyal apabila suatu produk yang mereka beli maupun jasa yang mereka dapatkan dari para penjual mampu memberikan kepuasan tertinggi maka konsumen tersebut tidak akan beralih dengan produk atau merek lain. Adapun ciri-ciri apabila konsumen yang memiliki loyalitas yang tinggi terhadap suatu barang maupun jasa yang mereka dapatkan dari para penjual yaitu: melakukan pembelian produk kita secara berulang, membeli antar lini produk maupun jasa, menawarkan dan akan mengajak orang lain untuk membeli produk kita, menunjukkan kelebihan dari produk dan pelayanan kita kepada orang lain dari para pesaingnya.

Beberapa faktor yang dapat menjadikan loyalitas konsumen adalah kualitas dari produk dan juga promosi yang mereka lakukan untuk mendapatkan konsumen untuk membeli produk kita. Konsumen yang mendapatkan kepuasan dengan produk yang kita tawarkan dan juga jasa yang kita berikan kepada konsumen akan cenderung melakukan pembelian secara berulang. Salah satu faktor penting untuk mengembangkan suatu loyalitas konsumen pada produk kita. Apabila pemasar yang tidak memperhatikan produk yang kita tawarkan baik atau tidak akan menangung risiko tidak adanya loyalitas konsumen terhadap produknya lagi. Namun apabila jika pemasar sangat memperhatikan kualitas produk yang mereka jual bahkan dengan pelayanan jasa yang sangat baik maka akan menimbulkan loyalitas para konsumen untuk membeli kembali produk kita (Nurullaili, 2013).

Konsep ini akan mencakup kemungkinan besar dalam pembahasan layanan konsumen dimasa yang akan datang. Para konsumen yang loyal yaitu mereka yang akan membeli ulang dengan merek yang sama pula, tidak hanya mempertimbangkan merek yang sama, juga sama sekali tidak akan mencari informasiinformasi tentang merek lain yang menjadi pesaing pasar suatu perusahaan (Aris, 2016).

\section{METODE PENELITIAN}

Metode penelitian ini menggunakan pendekatan kwantitatif, adapun populasi dalam penelitian ini adalah konsumen yang datang membeli ke store Naughti Hijab yang diambil dari 2 tahun terakhir sebanyak 2360 konsumen. Dalam menentukan jumlah sampel, maka penulis menggunakan rumus slovin sebagai berikut: 
Rumus Slovin:

$$
n=\frac{N}{1+N(e)^{2}}
$$

Keterangan:

$\mathrm{n} \quad$ : Besar ukuran populasi

$\mathrm{N}$ : Jumlah sampel minimal

e : Nilai kritis atau batas ketelitian yang masih bisa ditolerir sebesar $10 \%$

Populasi konsumen dari Naughti Hijab Store sebanyak 2360 konsumen. Maka sampel yang diambil dalam penelitian ini menggunakan rumus slovin dengan tingkat kepercayaan $90 \%$ dan tingkat error sebesar 10\%Berikut merupakan jumlah sampel yang akan diguna kan dalam penelitian ini adalah sebagai berikut:

Rumus Slovin:

$$
\begin{gathered}
n=\frac{N}{1+N(e)^{2}} \\
n=\frac{2360}{1+2360(10 \%)^{2}} \\
n=95,93 \text { dibulatkan menjadi } 100 \text { sampel }
\end{gathered}
$$

\section{HASIL DAN PEMBAHASAN}

\section{Hasil Uji Validitas}

Berikut ini adalah hasil uji validitas menggunakan olah data spss :

\section{Hasil Uji Validitas}

\begin{tabular}{|c|l|l|l|}
\hline No Item & R hitung & r tabel & Keterangan \\
\hline \multicolumn{2}{|c|}{ Strategi Pemasaran Syariah } \\
\hline X1.1 & 0,548 & 0,1654 & Valid \\
\hline X1.2 & 0,679 & 0,1654 & Valid \\
\hline X1.3 & 0,717 & 0,1654 & Valid \\
\hline X1.4 & 0,696 & 0,1654 & Valid \\
\hline XI.5 & 0,586 & 0,1654 & Valid \\
\hline XI.6 & 0,636 & 0,1654 & Valid \\
\hline X1.7 & 0,668 & 0,1654 & Valid \\
\hline X1.8 & 0,570 & 0,1654 & Valid \\
\hline Kepuasan Konsumen \\
\hline X2.1 & 0,551 & 0,1654 & Valid \\
\hline X2.2 & 0,810 & 0,1654 & Valid \\
\hline X2.3 & 0,757 & 0,1654 & Valid \\
\hline X2.4 & 0,769 & 0,1654 & Valid \\
\hline X2.5 & 0,680 & 0,1654 & Valid \\
\hline X2.6 & 0,453 & 0,1654 & Valid \\
\hline X2.7 & 0,798 & 0,1654 & Valid \\
\hline X2.8 & 0,837 & 0,1654 & Valid \\
\hline X2.9 & 0,807 & 0,1654 & Valid \\
\hline X2.10 & 0,878 & 0,1654 & Valid \\
\hline X2.11 & 0,842 & 0,1654 & Valid \\
\hline X2.12 & 0,858 & 0,1654 & Valid \\
\hline
\end{tabular}

\begin{tabular}{|c|l|l|l|}
\hline No Item & R hitung & r tabel & Keterangan \\
\hline \multicolumn{2}{|c|}{ Kepercayaan Konsumen } \\
\hline X3.1 & 0,781 & 0,1654 & Valid \\
\hline X3.2 & 0,760 & 0,1654 & Valid \\
\hline X3.3 & 0,756 & 0,1654 & Valid \\
\hline X3.4 & 0,657 & 0,1654 & Valid \\
\hline X3.5 & 0,719 & 0,1654 & Valid \\
\hline X3.6 & 0,726 & 0,1654 & Valid \\
\hline Loyalitas Konsumen \\
\hline Y1 & 0,558 & 0,1654 & Valid \\
\hline Y2 & 0,645 & 0,1654 & Valid \\
\hline Y3 & 0,609 & 0,1654 & Valid \\
\hline Y4 & 0,687 & 0,1654 & Valid \\
\hline Y5 & 0,758 & 0,1654 & Valid \\
\hline Y6 & 0,768 & 0,1654 & Valid \\
\hline Y7 & 0,682 & 0,1654 & Valid \\
\hline Y8 & 0,729 & 0,1654 & Valid \\
\hline Y9 & 0,595 & 0,1654 & Valid \\
\hline Y10 & 0,784 & 0,1654 & Valid \\
\hline Y11 & 0,629 & 0,1654 & Valid \\
\hline Y12 & 0,765 & 0,1654 & Valid \\
\hline
\end{tabular}

(Sumber Data primer diolah SPSS, 2020)

Berdasarkan tabel 1 maka dapat diketahui bahwa pada tabel Corrected Item-Total Correlation setelah dibandingkan dengan $r$ tabel dengan jumlah sampel (n) sebanyak 100 dengan df (degree of freedom) $=98$, dapat diketahui $r$ tabel sebesar 0,1654. Hal ini menunjukkan bahwa nilai $r$ hitung $>\mathrm{r}$ tabel. Maka pertanyaan-pertanyaan yang termuat dalam kuisioner tersebut valid, maka dapat dijadikan sebagai alat ukur untuk mengambil data dalam penelitian ini.

\section{Hasil Uji Reliabilitas}

Hasil uji reliabilitas dalam penelitian ini adalah sebagai berikut :

\section{Hasil Uji Reliabilitas}

\begin{tabular}{|l|l|l|l||}
\hline \multicolumn{1}{|c|}{ Variabel } & $\begin{array}{c}\text { Cronbach } \\
\text { Alpha }\end{array}$ & $\begin{array}{l}\text { Critical } \\
\text { Value }\end{array}$ & Keterangan \\
\hline $\begin{array}{l}\text { Strategi Pemasaran } \\
\text { Syariah (X1) }\end{array}$ & 0,787 & 0,6 & Realiabel \\
\hline $\begin{array}{l}\text { Kepuasan } \\
\text { Konsumen (X2) }\end{array}$ & 0,930 & 0,6 & Realiabel \\
\hline $\begin{array}{l}\text { Kepercayaan } \\
\text { Konsumen (X3) }\end{array}$ & 0,825 & 0,6 & Realiabel \\
\hline $\begin{array}{l}\text { Loyalitas Konsumen } \\
(Y)\end{array}$ & 0,896 & 0,6 & Realiabel \\
\hline
\end{tabular}

(Sumber Data Primer SPSS, 2020)

Berdasarkan tabel 2 diatas hasil uji reliabilitas terhadap kuisioner memperoleh koefisien reliabilitas sebesar 0,787, dengan nilai Cronbach Alpha >0,06, sehingga dapat disimpulkan bahwa hasil uji reliabilitas $\mathrm{X}_{1}$ merupakan reliabel. Terhadap kuisioner 
memperoleh koefisien reliabilitas sebesar 0,930, dengan nilai Cronbach Alpha $>0,06$, sehingga dapat disimpulkan bahwa hasil uji reliabilitas $\mathrm{X}_{2}$ merupakan reliabel. Terhadap kuisioner memperoleh koefisien reliabilitas sebesar 0,825, dengan nilai Cronbach Alpha $>0,06$, sehingga dapat disimpulkan bahwa hasil uji reliabilitas $X_{3}$ merupakan reliabel. Terhadap kuisioner memperoleh koefisien reliabilitas sebesar 0,896, sehingga dapat disimpulkan bahwa hasil uji reliabilitas Y merupakan reliabel.

\section{Hasil Uji Normalitas}

Uji normalitas data yang digunakan dalam penelitian ini adalah dengan uji One-Sample Kolmogorov-Smirnov Test dalam program SPSS. Uji yang digunakan untuk menguji apakah dalam model regeresi ini, variabel terikat, variabel bebas, keduanya mempunyai distribusi normal atau tidak. Uji normalitas pada penelitian ini dengan menggunakan uji. Hasil uji normalitas penelitian dapat dilihat dari tabel berikut:
Hasil Uji Normalitas

One-Sample Kolmogorov-Smirnov Test

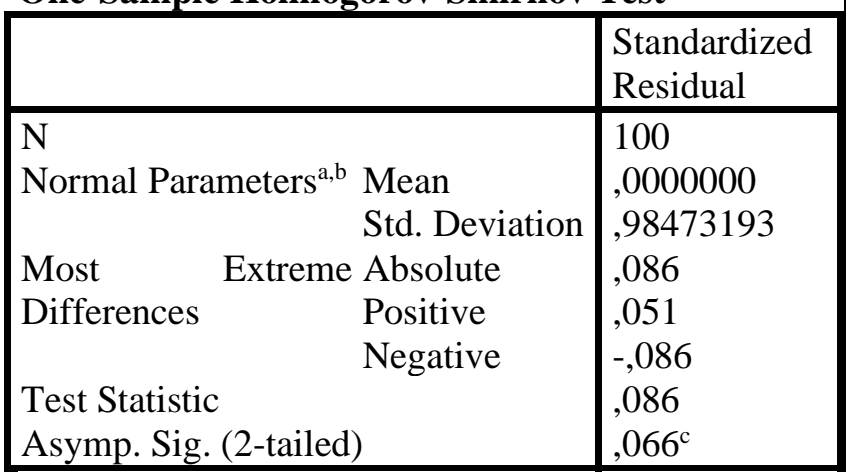

a. Test distribution is Normal.

b. Calculated from data.

c. Lilliefors Significance Correction.

Pada tabel 3 diatas menunjukkan bahwa hasil uji normalitas dengan uji One-Sampel KolmogorovSmirnov Test memberikan nilai Asymp.sig (2-tailed) sebesar 0,066 dan nilainya $>0,05$. Berdasarkan hal ini maka dapat disimpulkan bahwa data dalam penelitian ini terdistribusi dengan normal.

\section{Hasil Uji Multikolinieritas}

Hasil uji multikolinieritas dapat dilihat sebagai berikut :

\section{Hasil Uji Multikolinieritas}

Coefficients $^{\mathbf{a}}$

\begin{tabular}{|c|c|c|c|c|c|c|c|c|}
\hline \multirow{2}{*}{\multicolumn{2}{|c|}{ Model }} & \multicolumn{2}{|c|}{$\begin{array}{l}\text { Unstandardized } \\
\text { Coefficients }\end{array}$} & \multirow{2}{*}{$\begin{array}{l}\text { Standardized } \\
\text { Coefficients } \\
\text { Beta }\end{array}$} & \multirow[b]{2}{*}{$\mathrm{t}$} & \multirow[b]{2}{*}{ Sig. } & \multicolumn{2}{|c|}{$\begin{array}{l}\text { Collinearity } \\
\text { Statistics }\end{array}$} \\
\hline & & B & Std. Error & & & & Tolerance & VIF \\
\hline \multirow[t]{4}{*}{1} & (Constant) & ,213 & 3,787 & & ,056 & ,955 & & \\
\hline & TOTAL_X1 & 1,005 & ,152 & ,597 & 6,606 &, 000 & ,520 & 1,921 \\
\hline & TOTAL_X2 &,- 061 &, 110 &,- 062 &,- 553 & ,581 & ,336 & 2,979 \\
\hline & TOTAL_X3 & ,650 & ,266 & ,284 & 2,443 &, 016 & ,314 & 3,182 \\
\hline
\end{tabular}

a. Dependent Variable: TOTAL_Y

sumber : Data Primer diolah SPSS,2020

Berdasarkan tabel 4 menunjukan bahwa hasil perhitungan nilai tolerance dan nilai VIF pada variabel-variabel yang digunakan dalam penelitian ini jika dilihat dari nilai tolerance maka tidak terdeteksi multikolinearitas antar variabel, karena tiap variabel memiliki nilai tolerance $>0,1$. Untuk variabel $\mathrm{X}_{1}$ (Strategi Pemasaran Syariah) memiliki nilai tolerance sebesar 0,520, variabel $\mathrm{X}_{2}$ (Kepuasan Konsumen) memiliki nilai tolerance sebesar 0,336, dan variabel $\mathrm{X}_{3}$ (Kepercayaan konsumen) memiliki nilai tolerance sebesar 0,314 .

Hasil perhitungan VIF juga menunjukkan bahwa masing-masing variabel memiliki nilai VIF $<10$. Untuk variabel $\mathrm{X}_{1}$ (Strategi Pemasaran Syariah) memiliki nilai VIF sebesar 1,921, variabel $\mathrm{X}_{2}$ (Kepuasan Konsumen) memiliki nilai VIF sebesar
2,979, dan variabel $\mathrm{X}_{3}$ (Kepercayaan Konsumen) memiliki nilai VIF sebesar 3,182.

\section{Hasil Uji Heteroskedastisitas}

Hasil uji heteroskedastisitas dapat dilihat dalam tabel berikut :

\section{Hasil Uji Heterokedastisitas}

Coefficients ${ }^{\mathrm{a}}$

\begin{tabular}{|c|c|c|c|c|c|}
\hline \multirow[b]{2}{*}{ Model } & \multicolumn{2}{|c|}{$\begin{array}{l}\text { Unstandardized } \\
\text { Coefficients }\end{array}$} & \multirow{2}{*}{\begin{tabular}{|l|} 
Standardized \\
Coefficients
\end{tabular}} & \multirow[t]{2}{*}{$\mathrm{t}$} & \multirow[t]{2}{*}{ Sig. } \\
\hline & B & \begin{tabular}{|l} 
Std. \\
Error
\end{tabular} & & & \\
\hline 1 (Constant) & ,000 & ,005 & &,- 060 & ,952 \\
\hline $\mathrm{X} 1$ & $-2,553 \mathrm{E}-6$ & ,000 &,- 179 & $-1,117$ & ,267 \\
\hline $\mathrm{X} 2$ & 079 & ,059 & ,260 & 1,346 & ,181 \\
\hline $\mathrm{X} 3$ & ,091 & ,141 & 147 & 643 & ,522 \\
\hline
\end{tabular}

a. Dependent Variable: ABS

Sumber : Data primer diolah SPSS, 2020 
Berdasarkan tabel diatas dapat diketahui bahwa variabel strategi pemasaran syariah $\left(\mathrm{X}_{1}\right)$, kepuasan konsumen $\left(\mathrm{X}_{2}\right)$, kepercayaan konsumen $\left(\mathrm{X}_{3}\right)$ memiliki nilai signifikansi lebih besar dari 0.05 dengan nilai signifikansi strategi pemasaran syariah $\left(\mathrm{X}_{1}\right)$ sebesar 0,267, signifikansi kepuasan konsumen $\left(\mathrm{X}_{2}\right)$ sebesar 0,181 , dan signifikansi kepercayaan konsumen $\left(\mathrm{X}_{3}\right)$ sebesar 0,522. Jadi dapat disimpulkan bahwa model regresi dalam penelitian ini tidak mengandung adanya gejala heterokedastisitas, maka dikatakan valid.

Bisa juga dapat melihat hasil dari gambar dari Scatterplot buat melihat hasil dari uji heterokedastisitas sebagai berikut :

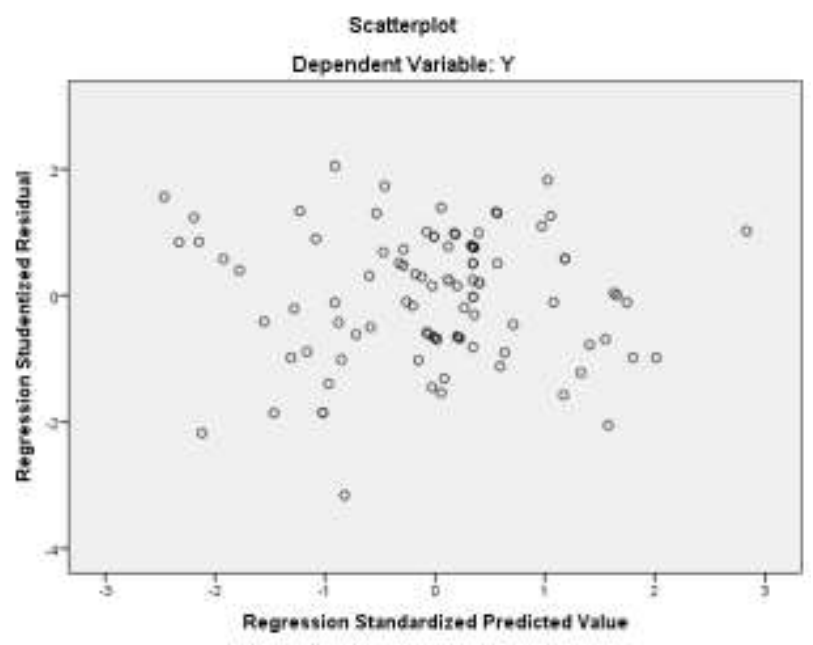

Gambar 1

\section{Uji heterokedastisitas}

Dapat dilihat dari gambar 1 diatas bahwa titiktitik yang dihasilkan pada grafik memiliki pola yang tidak jelas, seperti titik-titik menyebar diatas dan dibawah angka 0 pada sumbu $\mathrm{Y}$, sehingga dapat disimpulkan bahwa tidak dapat adanya gejala heterokedastisitas.

\section{Hasil Uji Autokorelasi}

Hasil penelitian dapat dilihat dari tabel berikut:

Model Summary ${ }^{b}$

\section{Hasil Uji Autokorelasi}

\begin{tabular}{|l|l|l|l|l|l|}
\hline Model & $\mathrm{R}$ & $\begin{array}{l}\mathrm{R} \\
\text { Square }\end{array}$ & $\begin{array}{l}\text { Adjusted } \\
\text { R Square }\end{array}$ & $\begin{array}{l}\text { Std. Error of } \\
\text { the Estimate }\end{array}$ & $\begin{array}{l}\text { Durbin- } \\
\text { Watson }\end{array}$ \\
\hline 1 &, $769^{\mathrm{a}}$ &, 592 &, 579 & 3,796 & 1,840 \\
\hline
\end{tabular}

a. Predictors: (Constant), X3, X1, X2

b. Dependent Variable: Y

Sumber : Data primer diolah SPSS,2020

Berdasarkan tabel diatas menunjukkan bahwa nilai yang dihasilkan oleh Durbin Watson ( $d w$ ) yaitu sebesar 1,840 lebih besar dari batas (du) 1,7364 dan kurang dari 4-du $(4-1,7364=2,2636)$ atau $(1,7364<$
$1,840<2,2636)$ yang memenuhi syarat DurbinWatson yaitu du $<\mathrm{dw}<4$-du. Hal ini dapat dinyatakan model regresi tersebut tidak terjadi gejala autokorelasi.

\section{Hasil Analisis Regresi Linear Berganda}

Hasil uji regresi linear berganda adalah sebagai berikut :

\section{Coefficients $^{\text {a }}$}

\section{Hasil Uji Regresi Linear Berganda}

\begin{tabular}{|l|l|l|l|l|l|}
\hline \multirow{2}{*}{} & \multicolumn{2}{|l|}{$\begin{array}{l}\text { Unstandardized } \\
\text { Coefficients }\end{array}$} & $\begin{array}{l}\text { Standardized } \\
\text { Coefficients }\end{array}$ & $\mathrm{t}$ & Sig. \\
\cline { 2 - 7 } Model & $\mathrm{B}$ & $\begin{array}{l}\text { Std. } \\
\text { Error }\end{array}$ & Beta & & \\
\hline 1 (Constant) &, 213 & 3,787 & &, 056 &, 955 \\
\hline X1 & 1,005 &, 152 &, 597 & 6,606 &, 000 \\
\hline X2 &,- 061 &, 110 &,- 062 &,- 553 &, 081 \\
\hline X3 &, 650 &, 266 &, 284 & 2,443 &, 016 \\
\hline
\end{tabular}

a. Dependent Variable: Y

Sumber: Data Primer yang diolah, 2020

Berdasarkan pada persamaan regresi linear berganda adalah sebagai berikut:

$\mathbf{Y}=\mathbf{a}+\mathbf{b}_{\mathbf{1}} \mathbf{X}_{\mathbf{1}}+\mathbf{b}_{\mathbf{2}} \mathbf{X}_{\mathbf{2}}+\mathbf{b}_{\mathbf{3}} \mathbf{X}_{\mathbf{3}}+\mathbf{e}$

$\mathrm{Y}=0,213+1,005 \mathrm{X}_{1}+0,061 \mathrm{X}_{2}+0,065 \mathrm{X}_{3}+\mathrm{e}$

Dari hasil persamaan regresi linear berganda tersebut diatas, maka di interprestasikan sebagai berikut :

a. Konstanta sebesar 0,213 yang artinya, jika variabel strategi pemasaran syariah $\left(\mathrm{X}_{1}\right)$, kepuasan konsumen $\left(\mathrm{X}_{2}\right)$, dan kepercayaan konsumen $\left(\mathrm{X}_{3}\right)$ dianggap konstan, maka skor variabel loyalitas konsumen (Y) nilainya 0,213 yang artinya, tanpa adanya strategi pemasaran syariah, kepuasan konsumen, dan kepercayaan konsumen maka loyalitas konsumen pada Naughti Hijab Store akan mengalami penurunan.

b. Koefisien strategi pemasaran syariah $\left(\mathrm{X}_{1}\right)$ sebesar 1,005 yang artinya, setiap kenaikan variabel strategi pemasaran syariah sebesar satu satuan, maka akan meningkatkan loyalitas konsumen sebesar 1,005.

c. Koefisien regresi kepuasan konsumen $\left(\mathrm{X}_{2}\right)$ sebesar 0,061 yang artinya, setiap kenaikan variabel kepuasan konsumen sebesar satu satuan, maka akan meningkatkan loyalitas konsumen sebesar 0,061 .

d. Koefisien regresi kepercayaan konsumen $\left(\mathrm{X}_{3}\right)$ sebesar 0,065 yang artinya, setiap kenaikan variabel kepercayaan konsumen sebesar satu satuan, maka akan meningkatkan loyalitas konsumen sebesar 0,065. 
Hasil Uji Parsial (Uji t)

Hasil uji t sebagai berikut :

Hasil Uji t

\begin{tabular}{|l|c|c|c|}
\hline Variabel & thitung $_{\text {Sign. }}$ & Keterangan \\
\hline $\begin{array}{l}\text { Strategii } \\
\text { Pemasaran } \\
\text { Syariah (X1) }\end{array}$ & 6,606 & 0,000 & Signifikan \\
$\begin{array}{l}\text { Kepuasan } \\
\text { Konsumen (X2) }\end{array}$ & 0,553 & 0,081 & Tidak Signifikan \\
$\begin{array}{l}\text { Kepercayaan } \\
\text { Konsumen (X3) }\end{array}$ & 2,443 & 0,016 & Signifikan \\
\hline
\end{tabular}

Sumber : Data yang diolah SPSS, 2020

Dari hasil uji t tersebut diatas, maka dapat di interprestasikan sebagai berikut :

a. Hasil $t_{\text {hitung }}$ strategi pemasaran syariah $\left(\mathrm{X}_{1}\right)$ sebesar 6,606 sedangkan hasil $t_{\text {tabel }}$ sebesar 1,9850 , maka nilai $t_{\text {hitung }}>\mathrm{t}_{\text {tabel }}$. Sementara nilai signifikansi variabel strategi pemasaran syariah $\left(\mathrm{X}_{1}\right)$ sebesar 0,000 maka signifikansi $<0,05$. Berdasarkan hasil tersebut maka Ho ditolak dan Ha diterima yang berarti bahwa variabel strategi pemasaran syariah berpengaruh terhadap loyalitas konsumen $(\mathrm{Y})$.

b. Hasil t hitung kepuasan konsumen $\left(\mathrm{X}_{2}\right)$ sebesar 0,553 sedangkan hasil $t_{\text {tabel }}$ sebesar 1,9850, maka nilai $t_{\text {hitung }}<\mathrm{t}_{\text {tabel. }}$. Sementara itu nilai signifikansi variabel kepuasan konsumen $\left(\mathrm{X}_{2}\right)$ sebesar 0,081 maka nilai signifikansi $>0,05$. Berdasarkan hasil tersebut maka Ho diterima dan Ha ditolak yang berarti bahwa variabel kepuasan konsumen tidak berpengaruh terhadap loyalitas konsumen $(\mathrm{Y})$.

c. Hasil $t_{\text {hitung }}$ kepercayaan konsumen $\left(\mathrm{X}_{3}\right)$ sebesar 2,443 sedangkan hasil $t_{\text {tabel }}$ sebesar 1,9850, maka nilai $t_{\text {hitung }}>t_{\text {tabel. }}$. Sementara itu nilai signifikansi variabel kepercayaan konsumen $\left(\mathrm{X}_{3}\right)$ sebesar 0,016 maka nilai signifikansi $<0,05$. Berdasarkan hasil tersebut maka Ho ditolak dan Ha diterima yang berarti bahwa variabel kepercayaan konsumen berpengaruh terhadap loyalitas konsumen (Y).

\section{Hasil Uji Simultan (Uji F)}

Hasil uji F variabel strategi pemasaran syariah, kepuasan konsumen, dan kepercayaan konsumen adalah sebagai berikut :

\section{Hasil Uji F}

ANOVA $^{\mathrm{a}}$

\begin{tabular}{|l|l|l|l|l|}
\hline Model & Sum of Squares & Df & Mean Square & F \\
\hline 1 Regression & 2007,839 & 3 & 669,280 & 46, \\
Residual & 1383,071 & 96 & 14,407 & \\
Total & 3390,910 & 99 & & \\
\hline
\end{tabular}

a. Dependent Variable: $\mathrm{Y}$

b. Predictors: (Constant), X3, X1, X2

Sumber : Data primer diolah SPSS, 2020
Pada tabel diatas menunjukkan nilai signifikansi sebesar $0,000<0,05$, maka model regresi yang digunakan tersebut sudah tepat, sehingga dapat disimpulkan bahwa terdapat pengaruh signifikan antara variabel strategi pemasaran syariah, kepuasan konsumen, dan kepercayaan konsumen terhadap loyalitas konsumen.

\section{Hasil Uji Koefisien Determinasi $\left(\mathbf{R}^{2}\right)$}

Hasil uji koefisien determinasi adalah sebagai berikut :

Hasil Uji Koefisien Determinasi $\left(\mathbf{R}^{2}\right)$

Model Summary ${ }^{\mathrm{b}}$

\begin{tabular}{|l|l|l|l|l|}
\hline Model & $\mathrm{R}$ & $\begin{array}{l}\mathrm{R} \\
\text { Square }\end{array}$ & $\begin{array}{l}\text { Adjusted R } \\
\text { Square }\end{array}$ & $\begin{array}{l}\text { Std. Error of the } \\
\text { Estimate }\end{array}$ \\
\hline 1 &, $769^{\mathrm{a}}$ &, 592 &, 579 & 3,796 \\
\hline
\end{tabular}

a. Predictors: (Constant), X3, X1, X2

b. Dependent Variable: Y

Sumber : data primer diolah SPSS, 2020

Pada tabel diatas dapat didapatkan nilai Adjusted $R$ Square adalah 0,579 hal ini variasi berarti loyalitas konsumen dijelaskan oleh variabel independent strategi pemasaran syariah, kepuasan konsumen, dan kepercayaan konsumen sebesar 57,9\%. Sedangkan sisanya dipengaruhi oleh variabel lainnya.

\section{Pembahasan Hasil Penelitian}

Penelitian ini dilakukan untuk mengetahui apakah pengaruh variabel strategi pemasaran syariah $\left(\mathrm{X}_{1}\right)$ terhadap loyalitas konsumen di Naughti Hijab Store, pengaruh variabel kepuasan konsumen $\left(\mathrm{X}_{2}\right)$ terhadap loyalitas konsumen di Naughti Hijab Store, pengaruh variabel kepercayaan konsumen $\left(\mathrm{X}_{3}\right)$ terhadap loyaltas konsumen di Naughti Hijab Store. Pembahasan masing-masing disajikan sebagai berikut:

a. Strategi Pemasaran Syariah Berpengaruh Terhadap Loyalitas Konsumen pada Naughti Hijab Store

Hasil penelitian menunjukkan bahwa variabel strategi pemasaran syariah $\left(\mathrm{X}_{1}\right)$ berpengaruh signifikan terhadap loyalitas konsumen (Y) dalam mempeli produk dari Naughti Hijab Store. Hal $/$ Sig $g_{\text {dih }}$ silkan berdasarkan nilai $t_{\text {hitung }}>t_{\text {tabel }}$ 6,455 yat $08,0^{b} 00>1,9850$ dengan signifikansinya seb $\$$ sar $0000<0,05$. Sehingga dapat disimpulkar bahwa strategi pemasaran syariah berpengaruh signifikan terhadap loyalitas konsumen. 
b. Kepuasan Konsumen Tidak Berpengaruh Terhadap Loyalitas Konsumen Pada Naughti Hijab Store

Hasil penelitian menunjukkan bahwa variabel kepuasan komsumen $\left(\mathrm{X}_{2}\right)$ tidak berpengaruh signifikan terhadap loyalitas konsumen $(\mathrm{Y})$. Hal ini dihasilkan berdasarkan nilai $\mathrm{t}_{\text {hitung }}<\mathrm{t}_{\text {tabel }}$ yaitu $0,553<1,9850$ dengan signifikansinya sebesar $0,081>0,05$. Sehingga dapat disimpulkan bahwa kepuasan konsumen tidak berpengaruh signifikan terhadap loyalitas konsumen (Y).

c. Kepercayaan Konsumen Berpengaruh Terhadap Loyalitas Konsumen Pada Naughti Hijab Store

Hasil penelitian menunjukkan bahwa variabel kepercayaan konsumen $\left(\mathrm{X}_{3}\right)$ berpengaruh signifikan terhadap loyalitas konsumen (Y). Hal ini dihasilkan berdasarkan nilai $t_{\text {hitung }}>t_{\text {tabel }}$ yaitu $2,443>1,9850$ dengan signifikansinya sebesar $0,016<0,05$. Sehingga dapat disimpulkan bahwa kepercayaan konsumen berpengaruh signifikan terhadap loyalitas konsumen (Y).

d. Pengaruh Strategi Pemasaran Syariah, Kepuasan Konsumen, dan Kepercayaan Konsumen secara bersama-sama berpengaruh terhadap Loyalitas Konsumen Pada Naughti Hijab Store

Berdasarkan hasil uji $\mathrm{F}$ didapatkan hasil bahwa nilai $\mathrm{F}$ hitung sebesar 46,455 dengan nilai signifikan 0,000 . Karena nilai signifikan yang didapatkan < 0,05, maka dapat disimpulkan bahwa strategi pemasaran syariah, kepuasan konsumen, dan kepercayaan konsumen berpengaruh secara simultan terhadap loyalitas konsumen pada Naughti Hijab Store. Berdasarkan hasil pengujian koefisien determinasi $\left(\mathrm{R}^{2}\right)$ sebesar 0,579. Dari hasil tersebut dapat disimpulkan bahwa variabel strategi pemasaran syariah, kepuasan konsumen, dan kepercayaan konsumen secara bersama-sama berpengaruh terhadap loyalitas konsumen pada Naughti Hijab Store sebesar 57,9 \% dan sisanya dipengaruhi oleh variabel lain.

\section{KESIMPULAN}

Penelitian ini bertujuan untuk mengetahui pengaruh strategi pemasaran syariah, kepuasan konsumen, dan kepercayaan konsumen terhadap loyalitas konsumen di Naughti Hijab Store dapat ditarik kesimpulan sebagai berikut :
Variabel strategi pemasaran syariah $\left(\mathrm{X}_{1}\right)$ menunjukkan hasil dengan $t_{\text {hitung }}=6,606$ dan $t_{\text {tabel }}=$ 1,9850 dan tingkat signifikansi $=0,000$ dengan menggunakan batas signifikansi sebesar 0,05. Hal tersebut menyatakan bahwa nilai $\mathrm{t}_{\text {hitung }}>\mathrm{t}_{\text {tabel }}=6,606$ $>1,9850$ atau sig $<0,05=0,000<0,05$ yang artinya, bahwa Ho ditolak dan Ha diterima. Sehingga, dapat disimpulkan bahwa variabel strategi pemasaran syariah berpengaruh terhadap loyalitas konsumen.

Variabel kepuasan konsumen $\left(\mathrm{X}_{2}\right)$ menunjukkan hasil dengan $\mathrm{t}_{\text {hitung }}=0,553$ dan $\mathrm{t}_{\text {tabel }}=1,9850$ dan tingkat signifikansi $=0,081$ dengan menggunakan batas signifikansi sebesar 0,05. Hal tersebut menyatakan bahwa nilai $\mathrm{t}_{\text {hitung }}>\mathrm{t}_{\text {tabel }}=0,553<$ 1,9850 atau sig $<0,05=0,081>0,05$ yang artinya, bahwa Ho diterima dan Ha ditolak. Sehingga, dapat disimpulkan bahwa variabel kepuasan konsumen tidak berpengaruh terhadap loyalitas konsumen.

Variabel kepercayaan konsumen $\left(\mathrm{X}_{3}\right)$ menunjukkan hasil dengan $\mathrm{t}_{\text {hitung }}=2,443$ dan $\mathrm{t}_{\text {tabel }}=$ 1,9850 dan tingkat signifikansi $=0,016$ dengan menggunakan batas signifikansi sebesar 0,05. Hal tersebut menyatakan bahwa nilai $t_{\text {hitung }}>t_{\text {tabel }}=2,443$ $>1,9850$ atau sig $<0,05=0,016<0,05$ yang artinya, bahwa Ho ditolak dan Ha diterima. Sehingga, dapat disimpulkan bahwa variabel kepuasan konsumen berpengaruh terhadap loyalitas konsumen.

Dari hasil persamaan regresi berganda diketahui bahwa strategi pemasaran syariah, kepuasan konsumen, dan kepercayaan konsumen secara bersama-sama (simultan). Hal ini dibuktikan pada tabel 4.10 yang menunjukkan nilai signifikansi sebesar $0,000<0,05$, sehingga dapat disimpulkan bahwa terdapat pengaruh signifikan antara variabel strategi pemasaran syariah, kepuasan konsumen, dan kepercayaan konsumen terhadap loyalitas konsumen. Sedangkan hasil adjusted $R$ Square memiliki nilai sebesar 0,579. Dari hasil tersebut dapat disimpulkan bahwa variabel strategi pemasaran syariah, kepuasan konsumen, dan kepercayaan konsumen secara bersama-sama berpengaruh terhadap loyalitas konsumen pada Naughti Hijab Store sebesar 57,9 \% dan sisanya dipengaruhi oleh variabel lain.

\section{UCAPAN TERIMA KASIH}

Terimakasih kami haturkan kepada Ketua LPPM ITB AAS Surakarta dan khususnya kepada dewan redaksi Jurnal Ilmiah Ekonomi Islam ( JIEI) ITB AAS Surakarta yang telah memberikan kesempatan, sehingga tulisan saya bisa diterbitkan. 


\section{DAFTAR PUSTAKA}

Akila. 2017. "Pengaruuh Insentif dan Pengawasaan Terhadap Produktivitas Kerja Karyawan Pada CV.Vasel". Palembang: Fakultas Ekonomi universitas PGRI Palembang.

Ghozali, I. 2018. "Aplikasi Analisis Multivariate Program IBM SPSS 25”. Edisi 9. Semarang: UNDIP.

Halin, Hamid. Wijaya, Hendy. Yulsilpi Rinda. 2017. "Pengaruh Harga Jual Kaca Putri Silver Terhadap Nilai Penjualan Pada CV. Karunia Kaca". Palembang: Fakultas Ekonomi UIGM Palembang.

Monika, Damayanti. 2018. "Analisis data Pihak Ketiga Tingkat Bagi Hasil dan Moodal Sendiri Terhadap Pembiayaan Bagi Hasil Mudharabah”. Skripsi. Surakarta: Program Studi Akuntansi STIE Surakarta.

Mubarok, Nurul. 2017. "Strategi Pemasaran Islami Dalam Meningkatkan Penjualan Pada Butik Calista”. Strategi Pemasaran Islam. Vol. 3. No. 1.
Roselendro, Eddy Nugroho. 2014. " Analisis FaktorFaktor Yang Mempengaruhi pengangguran di Indonesia". Jakarta: Manajemen Universitas Mercu Buana Jakarta.

Sri Mulyani, Fetty Rahayu. Hufron, M. Khoirun ABS, M. 2018. "Pengaruh Penerapan Marketing Syariah, Kepuasan Nasabah, dan Kepercayaan Nasabah Terhadap Loyalitas Nasabah Pada BPRS Bumi Rinjani Kepanjen”. Malang: Manajemen Fakultas Ekonomi Universitas Islam Malang.

Sugiyono. (2010). Memahami Metode Penelitian Kualitatif. Bandung: Alfabeta.

Sumadi, S. (2017). Peran Manajemen Syariah Terhadap Peningkatan Kepuasan Pelanggan Pada Rumah Sakit Islam Di Kota Surakarta. Jurnal Ilmiah Ekonomi Islam, 3(02), 112-124.

Usrina, Nura. Anggraini Renni Isya M. 2017. Analisa Karakteristik Tarikan Pergerakan Pengunjung Kedai Kopi”. Banda Aceh: Teknik Sipil Universitas Syiah Kuala. 